\title{
Social Consequences of Environmental Change in the Niger Delta of Nigeria
}

\author{
Akachi Odoemene, Ph.D. \\ Department of History and International relations, Redeemer's University \\ Mowe, Ogun State, Nigeria \\ Tel: 234-805-235-1678Ｅ-mail: akaiolo@yahoo.com
}

Received: October 4, 2010

Accepted: February 28, 2011

doi:10.5539/jsd.v4n2p123

\begin{abstract}
The Niger Delta is dying. Petrobusiness activities have caused severe environmental damage and climate change in its communities thus leading to massive destruction of farmlands, wild and marine lives. This has not been without dire social consequences on local communities of the Niger Delta which are doubly impoverished with attendant increase in abuse occasioned by struggle for survival. This paper interrogates issues of interest in the concrete experiences of Niger Delta communities in Nigeria in relation to environmental change. It highlights the transition of the delta to its present state and explores the social consequences of this downturn in delta communities. It argues that while the destruction of traditional means of livelihood has forced Niger Delta peoples into an environment-related poverty, deteriorating living conditions, and massive underdevelopment, environmental change in the area has led to new patterns of adaptation and survival. Both primary and secondary sources were used for the purposes of the study.
\end{abstract}

Keywords: Oil exploitation, Environmental degradation and change, Social consequences, Niger Delta, Nigeria

\section{Introduction}

For decades, the economic and political dimensions of environmental governance and change has been at the centre of national and international public policy and academic debates; nevertheless, the social impacts of environmental change and the inadequacy of policies addressing them have remained at the margins of academic research. Though its relevance has been emphasized and reaffirmed in the Brundtland Report (1987), the Millennium Development Goals (2001), the Johannesburg Declaration on Sustainable Development (2002), they remain fringe issues in the global discourse on sustainable development. Hence, much should be done to conceptualize and interrogate the social dimensions of environmental change in mainstream socio-economic analysis. However, social dimension issues should not be overlooked as societies face potentially dramatic environmental changes thus have to undergo fundamental transformations to achieve sustainable development. Environmental change is principally caused by anthropogenic activities such as petrobusiness explorations and its consequences to human society are negative. It alters the normalcy of the environment and forces the inhabitants of the affected area into new ways of life and adaptations. The Niger Delta is highly susceptible to adverse environmental changes because it is an oil producing community located in the coastal region of the world; little wonder why reports on the environmental state of the community are conclusive that the area is rapidly becoming an ecological wasteland (Uyigue and Ogbeibu, nd:2).

This paper focuses on the socio-environmental interface which includes the risks, potentials, challenges and opportunities associated with environmental change, governance and adaptation within Niger Delta societies. It also examines how environmental change has affected social development, lifestyles, social norms and principles, as well as cultural and behavioral patterns of social adaptation in Niger Delta societies. Though there have been studies on the economics and politics of violent conflict relations between and/or among the state, petrobusinesses and diverse oil-bearing communities of the Niger Delta, this present study is devoted to research on the socio-cultural consequences and the implications of environmental change on Niger Delta communities; an area vastly neglected by researchers of the Niger Delta and its crises. Therefore, this study is a pragmatic shift from previous studies and a bridge in knowledge production. It also addresses current issues on the social, economic, political and theoretical dilemma of the human society and its significance with regards to development and policy related issues both locally and globally. 


\section{Geo-Ethnography of the Niger Delta}

The Niger River Delta lies in the Atlantic Coast of southern Nigeria, and "within the Ibo Plateau and the Cross River Valley" (Willinks Commission Report, 1957:9). It is between latitude $3^{\circ} \mathrm{N}$ and $6^{\circ} \mathrm{N}$, and longitude $5^{\circ} \mathrm{E}$ and $8^{\circ} \mathrm{E}$ (Ndubuisi \& Asia, 2007:18). A watery maze of intricate marshland, creeks, tributaries and lagoons flung across approximately 70,000 square kilometers, the delta has an extremely delicate and sensitive ecosystem. It is Africa's largest wetland and the second largest in the world after the Mississippi (Nseabasi, 2005:165). About 2,370 square kilometers of the Niger Delta area consist of rivers, creeks and estuaries while stagnant swamp covers about 8,600 square kilometers. The region's ecosystem is highly diverse and supportive of numerous species of terrestrial and aquatic flora and fauna. As a result of its delicate nature, it is susceptible to adverse environmental change.

Politically, the Niger Delta is a panoply of geographically contiguous area currently cutting across nine states in southern Nigeria namely Abia, Akwa Ibom, Bayelsa, Cross River, Delta, Edo, Imo, Ondo and Rivers states. It has 185 Local Government Areas (LGAs) divided into more than 2,000 communities (Tamuno, 2000; Chinweze and Abiola-Oloke, 2009). Also, the Niger Delta has several minority ethnic groups with a population of over 40 million people. The area accounts for more than $23 \%$ of Nigeria's total population (NPC, 2006), and has one of the highest population densities in the world, with 265 people per square kilometer (Balouga, 2009; Nyananyo, 2007). The Niger Delta is Nigeria's richest region; this is as a result of the products from crude oil existing in the area which makes Nigeria the largest petroleum producer in Africa and the sixth in the world. Resources (oil and gas) from the region are the main sources of revenue in Nigeria. Since the early 1990's petroleum production have accounted for more than $25 \%$ of the country's Gross Domestic Product (GDP), oil exports have accounted for over 95\% of its total export earnings and about 75\% of government revenue (Balouga, 2009:8). Despite its privileged endowments, the Niger Delta is still largely a rural area. This was underlined by the Willinks Commission (1957:5) about fifty-three years ago which described it as "poor, backward, and neglected." This description has not yet changed till date.

\section{[Figure 1 here].}

Since the time of the constitution of the Willinks Commission in 1956, 'the Niger Delta' has been a major problem at local and international levels due to its strategic position in national and international economies. Closely linked to this are issues of environmental change and human development, sustainable development, petroleum resource conflicts, self-determination, resource ownership and control as well as peace and conflict management which have become current global phenomena in national and international public policy, academic debates and discourses.

\section{Theoretical Framework}

This study's theoretical framework is based on Ulrich Beck's "Risk Society Theory," which suggests there is a movement away from traditional social institutions and industrial society, and towards a new society which is individual, global and self-confrontational (reflexive). It argues that the old institutions (economic, political, legal and technological) are no longer able to cope with the reflexive, modernised world, where the very technologies that formed the basis of social and economic progress now create massive threats (Blowers, 1997; Anderson, 2000). One of the main concepts of the risk society is that of reflexive modernity, which has several inter-linking threads. The first is the concept of globalisation, which diminishes the power of the nation-state. Going alongside this is an increase in the magnitude and complexity of risks that are now out of all proportion to any previously encountered, and have outgrown the regulatory ability of national state-based systems. The risks are also hidden, and require scientific knowledge for their understanding. As such, they can be concealed (Beck et al, 2003).

The risk society is also a society based on individualisation. Traditional social ties are being replaced by individualised, choice-based social, political and economic institutions, which while increasing freedom also increase the risks that individuals are forced to take, in areas such as employment and welfare. The politics associated with it is no longer based on the distribution of goods, but on the distribution of 'bads'. Individuals are no longer insulated from global economic risks either. Altogether, this has led to a sub-politics, whereby individuals group together to directly influence world affairs, and bypass traditional politics and political parties. As environmental issues and debates are very much in the news at present, the thesis of the risk society links these issues with unprecedented social and political changes (Anderson, 2000). This theory takes centre stage as a prime analytical rubric for understanding the dilemmas of late modernity. Risk, fear, an increasing distrust of science and technology and its profit driven outcomes, a common perception that there are now limits to scientific progress and further economic growth and industrialization, have become endemic features of late 
modern culture. It is, in one sense, an assessment of the role of technology on human well-being, but in another how the complex reflexive relationships between science, technology and social-political institutions structure outcomes over which our control and influence might now be challenged or compromised.

Ultimately, Beck's thesis is an attempt to understand this remarkable transformation in social attitudes and fears, and an attempt to examine the interstitial forces at play between technology, science, political and social institutions, and the risk consequences of these both for the individual and society as a whole. As we would observe later on, the complexities of problems, challenges and adaptations, such as those raised in this essay, are germane to the Risk Society Theory.

\section{Environmental Degradation of the Delta}

Decades after the first gush of oil in the creek-side village of Oloibiri, 80 kilometers west of Port Harcourt city, was discovered in 1956, petrobusinesses have transformed the remote Niger Delta wetland into an industrial wasteland. Owing to government complacency and, most importantly, connivance, there has been a total disregard for the social, political, economic and environmental sensibilities of the Niger Delta peoples by petrobusinesses operating in the region including Shell, Chevron, Agip, Total, Elf and Mobil. Since 1956, they have been adopting substandard practices thereby subjecting them to untold inhumanities and injustices. It is axiomatic to note that all stages of oil business activity - exploration, drilling and transportation - result in the destruction of natural environment and the livelihood of the local inhabitants dependent on the environment for survival (Saliu et al, 2007:278). Though oil seems to be important to the country's economy, the people of Niger Delta perceive its discovery in their homeland as a threat to their life-support system. For instance, records reveal that between 1976 and 1990, the Niger Delta region experienced 2,676 cases of oil spills (CLO, 1996 cit. Uyigue and Agho, 2007:15) and in 2010 a total of 3,203 cases were recorded (Daily Independent, 2010:7). These spills have destroyed farmlands, polluted surface and ground waters (Inoni et al, 2006), while fishing, hunting and forest products gathering - the traditional occupations of the Niger Delta peoples - have witnessed drawbacks (Onosode, 2001).

Similarly, gas flaring in the Niger Delta is a major source of Carbon and other gaseous substances that contaminate the air, land, shallow groundwater resources resulting in green house effect and global warming process (Ndubuisi \& Asia, 2007:20). A report by the Central Intelligence Agency (CIA) indicated that "everyday, eight million cubic feet of natural gas are burned off in flares that light the skies across the Delta..." (The Comet, 2001:12). A satellite-based study of the Niger Delta revealed that between 1986 and 2003, more than 50,000 acres of mangroves disappeared from the coast, largely because of oil and gas exploration as well as coastal erosions (Polgreen, 2007). All these are not only eliminating sustenance means but as a $2006 \mathrm{UN}$ report warns: "pushing the delta towards ecological disaster" (Ohiagbuchi, 2007:9). It is important to note that the effects of oil exploitation in the region have led to rapid and visible environmental and climate changes, which has dictated the nature and pace of social changes in the region.

\section{Social Consequences of the Niger Delta Crises}

As a result of the governments' interest in pecuniary gains and petrobusinesses' substandard operational policy, there exist some unpalatable social consequences of climate change in Niger Delta communities. These consequences are the effects of the conditions on the people as well as their reactions. Similarly, with the indigenes of the region resolute to defending their environmental and human rights, even violently where necessary, there are some significant changes in the peoples' social life, consequential to the changes being experienced in their native homelands. In this section, we would examine some of these social consequences of environmental degradation and climate change in the Niger Delta.

\subsection{Youth Militancy and Gangsterism}

Denial of benefits accrued from the natural resources of the Niger Delta and the destruction of its ecosystem have made the people advocate for self-determination, resource ownership and control - an off-shoot of the earlier agitations led by Isaac Adaka Boro and later, Kenule Saro-Wiwa. This political activism introduced by the two 'revolutionaries' made the people of Niger Delta aware that the government has alienated them from the oil wealth (Ibaba, 2008). This resulted in a social breakdown, as evidenced by generalized lawlessness in the Niger Delta:

During periods of anomie or social breakdown, society loses its grip on the people who would wish to act according to their own dictates and not that of the collectivity. At a time like this, it is very easy to mobilize the people into mass movements because they readily make themselves available. However, mass movements, which emerge under such circumstances, do not primarily 
aim at changing society but to escape from their perceived isolation. From this theoretical prism, people join social movements for the purpose of gaining a sense of belonging and significance, which the wider society denied them (Anele, 1999:171).

These ultimately led to a new level of protest and agitations which have been popularized through various declarations like the Ogoni Bill of Rights (1990), the Kaiama Declaration (1998) of the Ijaw, the Resolutions of the First Urhobo Economic Summit (1998), the Bill of Rights of the Oron People (1999), the Akalaka Declaration (1999) and the Warri Accord (1999). In all these declarations, self-determination, resource ownership and control were cardinal objectives (Ohuabudu, 2008:PC). Radical activism that followed these declarations metamorphosed into a resilient subculture of youth violence and rebelliousness, which are a clear signal of social disequilibrium (Jike, 2004:689). Such acts included the disruption of the activities of petrobusinesses in the Niger Delta by different protesting interest groups, especially those of women and the youth which witnessed intensification since the 1990s. Okonta (2006:23) explains this transformation:

The metamorphosis of political activism in the delta region from nonviolent advocacy to armed insurrection is partly explained by the deliberate infiltration of their ranks by government and oil company agents, thereby narrowing the civic options of those who refused to be co-opted. In desperation, elements of the latter group embraced the AK47 to seek redress.

This period (the 1990s) also coincided with the emergence of different pressure groups such as the Movement for the Emancipation of the Niger Delta (MEND), Niger Delta People's Volunteer Force (NDPVF), the Egbesu Boys, Martyrs Brigade, Coalition of Militant Action in the Niger Delta, Niger Delta People's Salvation Front, Niger Delta Vigilante (NDV), Joint Revolutionary Council and Militant Camps Across the Niger Delta, amongst other less prominent ones. These groups were responsible for violent attacks against petrobusinesses, destruction of oil facilities and installations as well as intimidation of oil workers to quit their jobs. Oil installations and pipelines belonging to the Nigeria National Petroleum Corporation (NNPC), the government-owned oil enterprise, were also targeted. This resulted in the loss of lives and property. The State's response to this development has been with further repression rather than dialogue and constructive management of the conflicts thus the Niger Delta struggles snowballed into another phase of kidnapping and hostage taking for huge ransoms.

\subsection{Kidnapping and Hostage Taking}

Niger Delta militants introduced worrisome dimensions of kidnapping and hostage taking in 2006. On January 11 of that year, four oil workers, Mikko Nichevi (Bulgarian), Harry Ebanks (Honduras), Arnold Laundry (American) and Nigel Watson Clark (Briton), were kidnapped and taken hostage in Bayelsa state after the declaration of Operation Orido Danger by MEND (ICG, 2006). By December 2006, a total of 24 incidents, involving 118 hostages, were recorded (Ibaba, 2008:14). The issues of kidnapping and hostage taking have been an insalubrious phenomenon of the Niger Delta society. This is fore grounded by Kolawole (2007) who observes that: "Kidnapping expatriates and toddlers may just be a child's play. Something more barbaric may be in the offing if we do not find a solution as soon as possible." It is noteworthy that this ill wind has already blown to many other parts. Today, most parts of the country especially the Southeastern parts, have been grossly terrorized by the use of this new crime trend. It has, unfortunately, become "the talk and trend of the day in the country since its debut in the delta" (Akalonu, 2010:PC).

Jike (2004:695) and Saliu et al (2007:276) persuasively argue that one might conceptualize youth violence, restiveness, and rebelliousness in the Niger Delta as various shades of reactions to a system that has fallen short of meeting the expectations of the youth. Due to this fact, conflicts occur as a response to the frustration over the non-actualization of set goals (Anikpo, 1998). The militants, however, see the kidnapping of expatriates as a way to force their collective admittance into the system they had hitherto been eliminated from. The insecurity created by these activities equally sustains illegal oil bunkering by the militants, which costs the country four to eighteen billion US Dollars worth of oil (Vanguard, 2008:1).

\subsection{State Violence and Suppression}

Due to the kind of wealth that the oil sector produces and the unimpressive way its affairs have been handled over the years, the petroleum industry has become a perfect conduit for corrupt government officials of successive administrations and petrobusiness executives to enrich themselves. This has always been one of the grounds for the Niger Delta agitations. Regrettably, the official response of the government has been more repression of the agitators through the deployment of military troops and Mobile Police units with mortal instructions. For instance, since the 1990s many delta communities have had military occupations just to secure the activities of petrobusinesses and combat youth militancy. The latest of these was the 2006 Joint Military 
Task Force (JTF) which was deployed to Rivers, Bayelsa and Delta states (Ohuabudu, 2008:PC; Ejibunu, 2007:23).

State violence in this context has been demonstrated in several forms: wanton killings, destruction of communities, abusive military occupation, and sexual abuses by government security operatives. One such case was that of Odi town (near Port Harcourt) in 2000. It is reliably reported that thousands of people were killed, while livestock, farms, public utilities and houses in the town were deliberately and totally destroyed and set ablaze by the rampaging Nigerian Army (ERA/FOE-Nigeria, 2002). Another angle to this could also be seen in the (mis)use and manipulation of rival gangs, known locally as 'cults', for selfish political and clandestine purposes. These cults have proven ties with political leaders in the delta region who use them during elections to intimidate opponents and rig votes (Polgreen, 2007). The down turn of this arrangement has brought so much violence to the region. Abati (2007:3) points out that

they are causing so much problem because they need to get even with the politicians who used them during the elections $(2003,2007)$, only to get into office and ignore them. They promise to kidnap both politicians and their relatives and make the area ungovernable... The hoodlums who are now kings of the territory acquired power and influence under the watch of political Godfathers who used them as political thugs and armed them with sophisticated weapons. The elections are over; the genie is out of the bottle; the boys with the arms and ammunition have found a new occupation in terrorism. And the matter is now beyond the Godfathers who dare not declare their association with "the boys" too openly. We are paying the price for bad leadership and bad politics.

In other words, politicians from the region also exploit the helpless situation of the Niger Delta youth, using them as political thugs who will rig elections in their favour, only to be abandoned after the politicians had secured political office.

A remarkable example in this regard is that of one of Nigeria's most corrupt politicians, Dr. Peter Odili, the medical doctor turned politician and erstwhile Governor of Rivers State (Ghazvinian, nd). He founded and worked hands in glove with two of the most notorious militants in the Niger Delta region, Alhaji Dokubo Asari, the leader of the NDPVF, and Mr. Ateke Tom, Asari's former colleague and later, founder of the NDV. This was in Dr. Odili's bid to win the governorship elections in Rivers state, alongside Mr. Abiye Sekibo as secretary to the state government (Asuni, 2009; Courson, 2009). By the end of 2007 and having used the groups to achieve his ambitions, Asari as well as Ateke and their rival groups had fallen out with Dr. Odili, thus making the scenario on the in-fighting dangerously complex (Asuni, 2009; Courson, 2009; Nwolise, 2007:PC; Ghazvinian, nd). The inability of Dr. Odili and his associates to contain the militia gangs became a bane of the Niger Delta, due to their militancy and gangsterism. This was pertinent because

Many militant groups were never disarmed after the elections were held, becoming in effect standing armies for their political patrons. But while the armed groups remained, their political allegiances constantly shifted. Sekibo found himself unable to reign in Ateke's excesses, and the pair had a falling out during the 2007 election campaign when the latter blew up several police stations in Port Harcourt, freeing his supporters but injuring many bystanders. However, by 2008 it seemed that Ateke and Sekibo had settled their differences and were reportedly working together once more to destabilize the current governor in Rivers State, who had fallen out with them and his former godfather, Odili (Asuni, 2009:13-14).

\subsection{Intractable Inter-Communal Conflicts}

Violent communal clashes have increased in the Niger Delta region, especially since the 1990s. Such conflicts were either inter or intra ethnic, or between oil-bearing communities and state and/or petrobusinesses. Most of these violent conflicts are another dimension to the State-sponsored violence against the people of the region. Inter- and intra-ethnic clashes are caused by the struggle for the ownership of resources, usually land, and the sharing of largesse and the spoils of oil from either the State or petrobusinesses. An in-depth analysis of the symptoms of such conflicts glaringly reveal the complicity of the State and/or the petrobusinesses operating in the area, both of who use it as a 'divide and rule tactics' (Iyayi, 2004). Many of these conflicts pitch one delta community against the other, sometimes occurring between/among groups with no previous history of antagonism. 


\subsection{Breakdown of Cultural Values and Mores}

Most communities of the Niger Delta are very traditional in their ways of life in that their cultures are central to their lives and guide their everyday activities and interactions. However, Jike (2004:698) notes that the once-revered values have become supplanted by fads, and the prospects of institutional continuity have become more cumbersome. Suddenly, the safety value and the social control for orderly individual conduct and group behavior have snapped and society is worse for it. Issues of ancestral worship or deification still feature prominently in the lives of Niger Delta peoples. Any disruption of such customary practice is unwelcome as it could severe the link between the living and the pantheon of forbears in such communities and their worldview. However, the activities of petrobusinesses have infringed on many communities rights as ancestral homelands have been desecrated and forcefully converted to other uses by petrobusinesses. The Ogoni/Shell crisis in the late 1990s had this feature (Jike, 2004:690).

The legendary 'respect for elders' in African societies has also been largely truncated in most Niger Delta communities (Jike, 2004). As a result, the typical Niger Delta youth sees the elder as corrupt, inept and the epitome of colossal failure:

The elder represents an era that is best forgotten, an era that disemboweled enormous resources from the Niger-Delta region with very little to show for infrastructures, development, or collective self-upliftment. It was an era when Niger-Delta resources were ferreted to build skyscrapers and overhead bridges in Lagos and Abuja while the local people had no access roads to their subsistent farms, an era where several persons died of preventable and curable diseases because of lack of health care delivery facilities, an era when children trekked 10 or more miles to attend the nearest primary school, an era when elders turned a blind eye when multinational companies began in earnest to desecrate and plunder ancestral homelands for narrow economic gains, an era of the Petroleum Act of 1969 and the Land Use Decree of 1978 when government usurped the holding rights of individuals and trampled on civil liberties with reckless abandon, and an era where a massive oil spillage with untold environmental consequences could be hushed up with a paltry compensation sum of N5,000 (5,000 naira/U.S. \$25) and a bottle of gin. This is the quintessential era of the elder that is best forgotten... [It] also explains why in every conflict, particularly in the Niger-Delta, the youths are more likely to hold on to a viewpoint that contrasts with those of their elders (Jike, 2004:696-7).

\subsection{Increased Poverty and Destitution amongst Indigenes}

The people of Niger Delta region are highly dependent on their environment (land, water and forest) for sustenance. They were attached to their environment and made their living from the exploitation of its resources as farmers, fishermen, hunters and forest product gatherers (Alamieyeseigha, 2005:3). As a result of environmental degradation and petrobusiness activities, the economic activities of the people were soon dislocated as the effects on farmlands, economic crops, creeks, lakes and rivers became so severe and devastating. Hence, the people could not engage in meaningful productive activities as they used to do (Uyigue and Agho, 2007:19; Alamieyeseigha, 2005:4). Due to this development, the dominant economic activity of the people has become traditional agrarian trading (Alamieyeseigha, 2005), while very few are employed in the industries and/or in the civil service. This impaired capacity of the people due to a degraded and devastated environment is a major cause of poverty in the region (Amnesty International, 2009; UNDP, 2006:175-311; Alamieyeseigha, 2005:5; World Bank Report, 1995).

Furthermore, the cost of goods and services in the Niger Delta are quite high compared to other parts of the country because of the presence of petrobusiness activities thereby birthing a high cost of living in the region. This is at the detriment of the local peoples because the more costly the prices of goods and services, the more the local people are impoverished (Uyigue and Agho, 2007:19 Iyayi 2004). An unfortunate aspect of this situation is the fact that Niger Delta indigenes are seldom employed by the petrobusinesses operating in the area, save for menial/low cadre positions.

The Nigerian government has made trillions of dollars from oil revenue in the last half a century of oil exploitation in the Niger Delta; despite this huge amount of money and the seemingly inexhaustible resource potentials of the Niger Delta, the people of the region remain in abject poverty and deprivation of the basic needs of life. In spite of being Africa's leading oil producing zone, the world development report shows that $36.4 \%$ of Niger Delta inhabitants live below poverty line and $70.2 \%$ of this proportion earn less than $\$ 1$ USD per day with a clear absence of the basic social amenities (World Bank, 2003; Balouga, 2009). The link between oil 
production activities and poverty in the Niger Delta is well articulated by Aaron (2006:194) who aptly opines thus:

Oil has meant for the indigenes of the Niger Delta, wrenching poverty... State laws and policies as they relate to petroleum resources, expropriate the indigenous peoples of the Niger Delta of their 'right' to their natural resources ... [T] he local economies of the Oil Producing Communities have collapsed. And they are not integrated into the oil economy of Nigeria ...[T]he success of the oil economy has not promoted their own capacities. It has not promoted their own self-reliance. It has not promoted the social engine of the society... The pace of development has left them.

Apart from the lack of income and assets to attain basic necessities of life, such as, food, shelter, clothing and access to acceptable levels of health care and education, poverty has other manifestations which include a sense of voicelessness and powerlessness in the affected society (Ijaiya and Umar, 2004:87). These manifestations subject the 'poor' to rudeness, humiliation, shame, inhuman treatment and exploitation in the hands of those in position of political power and authority. It speaks publicly through visible misery, persisting destitution, endemic hunger and visible malnutrition (Akanmidu, 2004:3), all characteristics of the delta communities.

\subsection{Reinforced Human Underdevelopment}

Diverse literature on the Niger Delta agrees that the oil industry has not promoted the development of the region; instead it has undermined the area's human development (Enyia, 1991; Ikein, 1991; Aaron, 2006). Undoubtedly, the combination of the various social consequences already discussed would unequivocally lead to human underdevelopment. Thus, this situation results as a consequence of the devalued nature of human existence in the region.

Although the region is well endowed with intelligent human resources, it has the highest illiteracy and unemployment rates in Nigeria. Its educational system has virtually collapsed over the years, while the infrastructure vital for quality education is grossly lacking, thus leading to high school dropout rates (Balouga, 2009:8). Indeed, education levels are below the national average and are particularly low for women. Statistics show that while $76 \%$ of Nigerian children attend primary school, this level drops to $30-40 \%$ in some parts of the Niger Delta. Unemployment rate in the region is reported to be 30\% (Uyigue and Agho, 2007:20). This is because of the low skills syndrome leading to the un-employability of the region's people. Again, change in means of livelihood from natural sectors to non-natural sectors due to the degraded and devastated environment has equally affected the people adversely. This has been especially in the agricultural and fishery sectors. Also, change in occupation has caused a high rate of rural - urban migration, which has particularly affected the productive workforce, especially those of the youthful age group in the rural communities.

The restiveness of the youth in the Niger Delta, as earlier discussed, has some consequences on the business sector as a good number of business firms in the area have stopped operations because of kidnapping, hostage taking and attack on oil instillations (Ejibunu, 2007:22). In reaction to this development, Mr. Tele Ikuru, the Deputy Governor of Rivers State, notes that the state has become a carcass of itself as about 80 per cent of companies in its most economically vibrant district have closed down, not because of their inability to manage businesses properly, but because of "the demonic activities of our youth" (Sunday Trust, nd). The sense of social inequity, deprivation and alienation felt by these people has been aptly highlighted by Jike (2001) and Ikporukpo (1988). In addition, as a consequence of the entire negative socio-environmental trends in Niger Delta communities:

The little school child is truant because the parents, having been displaced from their farms, are unable to meet their obligations to provide food and the recommended textbooks for the child at school. The fisherman sits very early in the day guzzling locally brewed gin (Ogogoro) in his sitting room because the fishes in his domain have been depleted, not by the plunderous activity of humans but by spillage and industrial effluents that have begun to introduce toxicity and distort aquatic balance, thereby forcing whole species to migrate or die. (Jike, 2004:692).

\section{Gender Dimensions of the Social Crises}

While one acknowledges that the social costs of environmental change in the Niger Delta has not been adequately articulated in scholarship, the gendering of these perspectives has been consistently neglected. Insights into this area are quite revealing as women even in the Niger Delta, suffer great hardships in times of conflict more than men. Two broad themes are focused on in this section: (1) the destruction of women's capacities, as well as limitation of their potentials for innovation and socio-economic development; (2) women's 
sexual exploitation by their men, the state and petrobusinesses. An aspect of women's social adaptations through a resilient agency for survival (including the imbibing of 'strange' cultures) is also highlighted.

In the socio-economic structure of Niger Delta communities, women are subordinate to men; this reinforces the double marginalization of the womenfolk in these communities. Though traditionally women of this region neither own nor inherit land, they bear the burden of raising and nurturing their families (household), sometimes as breadwinners. Thus, they provide the basic needs of their household: food, fuel and fodder through engaging mainly in fishing, farming and gathering of forest products. As the principal custodians of their communities, women are the major income earners in the region (Chinweze and Abiola-Oloke, 2009). However, the poor management of oil and gas resource in this region coupled with pressures arising from environmental changes has undermined the livelihoods of women and the income they generate to sustain their families. As the resourcefulness of these women depends totally on the viability of their environment, a degraded environment is a challenge on their socio-economic status; so the women have to over-exploit the slim natural resources available to them, in a bid to squeeze out a living for their families. As a result, the trends and developments underlining poverty and destitution affect women because of their socio-economic position in the society. This typically elucidates what could be referred to as "the feminization of poverty" - a phenomenon which is more evident in the Niger Delta than elsewhere in the country. Arguably, since women disproportionately bear the brunt of the Niger Delta injustices, one can also allude to "the feminization of the Niger Delta crisis," as Amakwe (nd:7) puts it.

Also, Ibeanu (2000) highlights the undergoing of the Ogoni women from violent men fighting for their rights; as under the disguise of frustration and deprivation, deluded young men of Niger Delta communities are known to be involved in criminal sexual acts that leave many women violated, dehumanized and 'broken' (Igbogbodu, 2010:PC).

Security forces sent by the government or petrobusinesses to contain "insurgency" in the Niger Delta use women's bodies as their battlefield. They invade private homes; terrorize residents with beatings and rape women and girls (Mortished, 1996:3). This was exemplified on 28 October 1999 when scores of women were raped by a contingent of Nigeria Mobile Police and soldiers who invaded Choba town in Port Harcourt city on the orders of Wilbros, an American oil servicing company in the community (Ekine 2005:75; IHRHL 2000; Amnesty International, nd). Furthermore, Odoemene (2008) extensively documented acts of sexual violence by Nigerian security forces (with the complicity of Shell Oil) against the Ogoni women of Niger Delta. Types of sexual violence referred to in his essay include rape, forced prostitution, sexual slavery, sex-related threats, sexual harassment (touching the breasts or bodies of women and young girls), and instances of forced pregnancy (Odoemene, 2008:5). These acts of sexual violations have grave socio-cultural implications, not only on the women victims, but also their families and communities (Dorothy and Regan, 1994; Odoemene, 2008).

As a fallout of the Niger Delta crisis, prostitution is common as girls and young women seeking economic survival involve in prostitution in major towns and cities of the Niger Delta. Amakwe (nd:5) notes that these women "are given few Naira or at most few dollars at the end of every sexual meeting." Similarly, certain Niger Delta cities, especially Port Harcourt, Warri, and Benin, have become sex haunts for "oil men" with young women from delta communities as their "human resources" (Igbogbodu, 2010:PC; Owuamalam, 2009:PC; Ohuabudu, 2008:PC). Even those in marriage are not left out:

The wives' tales... are that many wives abandon matrimony in preference for young White oil workers who have more than enough money to spend as opposed to their struggling husbands. ...As expected, among young couples divorce is on the rise (Jike, 2004:698).

Again, these cities now exhibit an unsavoury night-life which has been on the increase since the 1990s. Not only do these oil men have cheap sex at their disposal, but worse still, most of these relationships end up with children and the women are left alone to carry the burden of bringing up these 'fatherless babies' (Amakwe, nd). These trends connote a breakdown of societal moral fibre and social values, all of which these indigenous Niger Delta communities were reputed and respected for (Odoemene, 2010).

\section{Conclusion}

In its present state of human insecurity, the Niger Delta undeniably shows linkage to ecological disaster, environmental change, impoverishment and conflict (Obi, 2000). As such, the fundamental transformations which ensued in affected societies necessitated the modification of or even the departure from long-established, deeply rooted patterns of behaviour and lifestyles, cultural traditions, social norms and principles, or models of political and social organization and development. Even though the Niger Delta region bears Nigeria's riches and thus variously described as the "goose that lays Nigeria's golden egg" (Osaghae, 1991; 1995; ANEEJ, 2004), 
it is also home to some of Africa's poorest of the poor, and the theatre of the continent's worst environmental destruction (Robinson, 2006:20; Omotola, 2006:4). For their richly endowed environment, the people of the Niger Delta have known only poverty, misery and sorrow (Tell Magazine, 2005; Ake, 1994).

This paper has articulated the diverse social consequences of environmental change in the Niger Delta. These have included violence, crime, poverty, despondency, underdevelopment and the erosion of the society's social and moral fabric. In all these, women's social development is noted to be the most affected. Worse still, these women's sufferings often literarily pass unnoticed. As a result of the continued complicity of the State in the Niger Delta crises and the unyielding attitudes of petrobusinesses working in the area alongside the indignities, inhumanities and insecurities currently experienced, the agony in area would not abate soon. The continued destruction of the Niger Delta environment, its diverse social implications and the peoples' reactionary adaptations for survival, show that the region is constantly being pushed to the point of precipice.

Indeed, the paradoxical existence of both progress and risk comprise the principal themes of Beck's Risk Society theory (Henwood et al, 2010). Thus, despite the seemingly grim picture, there is an opportunity for a turn-around for good. The salvaging situation, therefore, would be the putting into place of responsible environmental governance that effectively responds to social consequences. Environmental actions must be improved to meet best practices elsewhere, which would simultaneously affect social conditions for development and may trigger social, political, and economic innovations that could create new opportunities for formerly disadvantaged and marginalized groups. This would ultimately increase environmental and social justice within and across societies. Likewise, it would improve social infrastructures, build capacities, and satisfy basic human needs alongside furthering sustainable development. If the social dimensions of the current crises are not proactively dealt with, the prophesy that the Niger Delta could develop into "the next Gulf" (Rowell et al, 2005) could be in the affirmative. This is even more worrisome in the light of Chris Alagoa's contention that "if the delta explodes, Nigeria goes with it" (Maier, 2000:111). But, what if the world paid attention before it was too late?

\section{References}

\section{Personal Communication}

Chidinma Akalonu (Lolo). 72 years, Woman Leader and Entrepreneur. Interviewed in Port Harcourt city (Nigeria) on Saturday, 8 April 2010.

Chukwudi Nwolise. 46 years, Academic/Researcher. Interviewed in Ibadan (Nigeria) on Wednesday, 24 October 2007.

Felix Igbogbodu. 52 years, Businessman and Farmer. Interviewed in Warri (Nigeria) on Thursday, 6 April 2010.

Mike Ohuabudu; 32 years, Unemployed Ikwerre Youth. Interviewed in Port Harcourt city (Nigeria) on Saturday, 15 March 2008.

Peter Owuamalam. 58 years, Public Relations Consultant. Interviewed in Owerri (Nigeria) on Sunday, 13 December 2009.

\section{Literature}

Aaron, K.K. (2006). Human Rights Violation and Environmental Degradation in the Niger Delta. In Porter, E. \& Offord, B. (eds.), Activating Human Rights (pp. 193 - 215). New York: Peter Long; Oxford: Borne.

Abati, R. (2007). Port Harcourt: A Paradise Lost. [Online] Available: http://www.nigeriavillagesquare.com/articles/reuben-abati/port-harcourt-a-paradise-lost/pdf.html. $\quad(29 \quad$ June 2008).

African Network for Environment and Economic Justice (ANEEJ). (2004). Oil of Poverty in Niger Delta. Benin City: ANEEJ.

Akanmidu, R.A. (2004). Poverty Alleviation Programmes and the Politics of Ethical Despair in Nigeria. Seventieth Inaugural Lecture, University of Ilorin, Ilorin, Nigeria.

Ake, C. (1994). A People Endangered by Oil. The Guardian Newspaper, 18 August, 23.

Alamieyeseigha, D.S.P. (2005). The Niger Delta Crises: Yesterday, Today and Tomorrow. Paper presented at the Institute of African Studies, University of Ibadan, Ibadan, Nigeria (15 March).

Amakwe, M.J.B. (nd). The Niger Delta Oil Crisis and the Victimisation of Women: A Socio-ethnographic Analysis.

[Online]

Available:

http://www.civilizationoflove.org/httpdocs/archives/voicewomen/The\%20Niger\%20Delta\%20oil\%20crisis\%20a nd\%20the\%20victimisation\%20of\%20women.pdf. (18 August 2010). 
Amnesty International. (2009). Nigeria: Petroleum, Pollution and Poverty in the Niger Delta. London: Amnesty International Publications.

Amnesty International. (nd). Nigeria: Rape - the Silent Weapon. [Online] Available: http://www.amnestyusa.org/document.php?id=ENGAFR440202006\&lang=e. (20 September 2009).

Anderson, A. (2000). Environmental pressure politics and the "risk society." In S. Allan, B. Adam, \& C. Carter (Eds.), Environmental risks and the media (pp. 93-104). London: Routledge.

Anele, K.A. (1999). Social Change and Social Problems in Nigeria. Owerri: Springfield Publishers.

Anikpo, M. (1998). Communal Conflict in the East Niger Delta: A Cultural Matrix. Pan African Social Science Review, Vol. 3.

Asuni, J.B. (2009). Understanding the Armed Groups of the Niger Delta. Working Paper, Council on Foreign Relations (CFR) (September).

Balouga, J. (2009). The Niger Delta: Defusing the Time Bomb. First Quarter (International Association for Energy Economics), 8-11.

Beck, U. (1992). Risk society: Towards a new modernity. London: Sage.

Beck, U., Bonss, W. \& Lau, C. (2003). The theory of reflexive modernization: problematic, hypotheses and research programme theory. Culture \& Society, 20 (2.2), 1-33.

Blowers, A. (1997). Environmental policy: ecological modernisation or the risk society? Urban Studies, 34 (5/6), 854-872.

Chinweze, C. \& Abiola-Oloke, G. (2009). Women Issues, Poverty and Social Challenge of Climate Change in the Nigerian Niger Delta Context. Paper presented at the 7th International Conference on the Human Dimension of Global Environmental Change (IHDP Open Meeting), UN Campus, Bonn, Germany; 26-30 April.

Courson, E. (2009). Movement for the Emancipation of the Niger Delta (MEND): Political Marginalization, Repression and Petro-insurgency in the Niger Delta. Discussion Paper 47, Nordiska Afrikainstitutet, Uppsala.

Daily Independent Newspaper. (2010). Nigeria: The Nation's 3,203 Oil Spills in Four Years. (Editorial) Lagos (12 August), 7-8.

Dorothy, Q.T. \& Regan, E.R. (1994). Rape in War: Challenging the Tradition of Impunity. SAIS Review 14 (1) (Winter/Spring), 81-99.

Ejibunu, H.T. (2007). Nigeria's Niger Delta Crisis: Root Causes of Peacelessness. EPU Research Papers, Issue 07/07, European University Center for Peace Studies (EPU), Stadtschlaining/Austria, 1-6.

Ekine, S. (2005). Women's Responses to State Violence in the Niger Delta. Feminist Africa 10, 67-84.

Enyia, N.T. (1991). Oil Exploration and Production in Rivers State: An Analysis of the Political and Socio-Economic Consequences for Six (6) Communities: 1950-1990. Unpublished Ph.D. Thesis, University of Port Harcourt, Nigeria.

ERA/FOE-Nigeria. (2002). A Blanket of Silence: Images of the Odi Genocide. Environmental Rights Action/Friends of the Earth-Nigeria. [Online] Available: http://www.eraction.org/publications/silence.pdf. (25 August 2008).

Ghazvinian, J. (nd). The Curse of Oil. [Online] Available: http://www.ijawland.com/The\%20Curse\%20of\%200il\%20by\%20John\%20Ghazvinian.pdf. (23 August 2008).

Henwood, K., Pidgeon, N., Parkhill, K.\& Simmons, P. (2010). Researching Risk: Narrative, Biography, Subjectivity [43 paragraphs]. Forum: Qualitative Social Research, 1 (1), Art. 20 (January). [Online] Available: http://nbn-resolving.de/urn:nbn:de:0114-fqs1001201. (23 January 2011).

Ibaba, S.I. (2008). Alienation and Militancy in the Niger Delta: Hostage Taking and the Dilemma of the Nigerian State. African Journal on Conflict Resolution 8 (2), 11-34.

Ibeanu, O.O. (2000). Insurgent Civil Society and Democracy in Nigeria: Ogoni Encounters with the State, 1990-1998. Research Report for ICSAG Programme of the Centre for Research and Documentation (CRD), Kano.

Idemudia, U. \& U.E. Ite (2006). Corporate - community relations in Nigeria's oil industry: challenges and imperatives. Corporate Social Responsibility and Environmental Management 13 (4) (September), 194-206. 
IHRHL. (2000). Poverty in Wealth: Report on the People of the Niger Delta and the display of Poverty in Wealth. Port Harcourt: Institute of Humanitarian Rights and Humanitarian Law (IHRHL), (September) [Online] Available: www.ihrhl-ng.org/poverty\%20in\%20wealth.doc. (23 June 2008).

Ikein, A.A. (1991). The Impact of Oil on a Developing Country: The Case of Nigeria. Ibadan: Evans Brothers Publishers Limited.

Ikporukpo, B.C.O. (1988). Managing Oil Pollution in Nigeria. In P.O. Sada \& F.O. Odemerho (Eds.), Environmental Issues and Management in Nigerian Development (pp. 224-9). Ibadan, Nigeria: Evans Brothers Ltd.

Inoni, O.E., Omotor, D.G. \& Adun, F.N. (2006). The Effect of Oil Spillage on Crop Yield and Farm Income in Delta State, Nigeria. Journal of Central European Agriculture 7 (1), 41-8.

International Crisis Group (ICG) (2006). Fuelling the Niger Delta Crisis. Africa Report No. 118 (28 September).

Iyayi, F. (2004). An Integrated Approach to Development in the Niger Delta. A paper prepared for the Centre for Democracy and Development (CDD).

Jike, V.T. (2001). Niger-Delta Environment, Agricultural Disorientation and the most probable Doomsday Scenario. Paper presented at the Population Dynamics of Nigeria Conference, University of Lagos (15-17October).

Jike, V.T. (2004). Environmental Degradation, Social Disequilibrium, and the Dilemma of Sustainable Development in the Niger-Delta of Nigeria. Journal of Black Studies 34 (5) (May), 686-701.

Kolawole, S. (2007). Kidnapping is a Child's Play. Thisday Newspaper. [Online Edition] Available: http://www.thisdayontheline.com. (21 September 2008).

Maier, K. (2000). This House Has Fallen: Nigeria in Crisis. London: Penguin Books.

Mortished, C. (1996). No Longer in Glorious Isolation: Shell Petroleum Development. Times Magazine, London (8 July), 1-4.

National Population Commission. (2006). Nigeria's National Census Figures. Abuja: NPC.

Ndubuisi, O.L. \& Asia, I.O. (2007). Environmental Pollution in Oil Producing Areas of the Niger Delta Basin, Nigeria: Empirical Assessment of Trends and People's Perception. Environmental Research Journal 1, 1-4.

Nseabasi, A. (2005). Conflicts in Nigeria's Niger-Delta: Issues on Response and Management. International Journal of Social Sciences 4 (1), 161-175.

Nyananyo, B.L. (2007). Global Warming and the Niger Delta Environment. A paper presented at the 2nd History Concourse on the Future of the Niger Delta: The Search for a Relevant Narrative, Department of History and International Studies, University of Calabar, Calabar, Nigeria (5 May).

O'neill, T. (2007). Curse of Black Gold: Hope and Betrayal in the Niger Delta. National Geographic, (February).

Obi, C. (2000). Economic Adjustment and the Deepening of Environmental Conflict in Africa. In L.A. Jinadu, (Ed.) The Political Economy of Peace and Security in Africa: Ethnic cultural and Economic Perspectives (pp. 1-11). Harare: AAPS Books.

Odoemene, A. (2008). The Nigerian Military and Sexual Violence in Ogoniland of (Niger Delta) Nigeria, 1990-1999. Paper presented at an international conference on Rape in Wartime: A History to be Written, Institut Historique Allemand, Paris, France, 11th - 14th May.

Odoemene, A. (2010). The African Extended Family System in Historical and Contemporary Contexts. In A. Osuntokun, V. Ukaogo \& A. Odoemene, (Eds.), Readings on Issues and Challenges of Nigerian Societies (pp. 143-57). Glassboro, NJ: Goldline and Jacobs Publishers.

Ohiagbuchi, J.C. (2007). Killing the Goose that Lays the Golden Egg: The Perils of the Niger Delta. Warri: Ohioma Publishers.

Okonta, I. (2006). Behind the Mask: Explaining the Emergence of the MEND Militia in Nigeria's Oil-Bearing Niger Delta. Niger Delta: Economies of Violence, Working Paper No. 11.

Omotola, J.S. (2006). 'The Next Gulf? Oil Politics, Environmental Apocalypse and Rising Tension in the Niger Delta. African Centre for the Constructive Resolution of Dispute (ACCORD), Occasional Paper Series 1 (3), $1-31$. 
Onosode, G.O. (2001). Oil Pollution and Environmental Management: Issues Arising. Keynote address at the 1st International Conference on Oil Pollution and Environmental Management. House of Representatives, National Assembly, Abuja, Nigeria.

Osaghae, E.E. (1991). Ethnic Minorities and Federalism in Nigeria. African Affairs 90 (355), 237-258.

Osaghae, E.E. (1995). The Ogoni Uprising: Oil Politics, Minority Agitation and the Future of the Nigerian State. African Affairs 94 (376), 325-344.

Polgreen, L. (2007). Nigerian Gangs turn their Guns on their Own. International Herald Tribune, (Thursday, November 8) [Online Edition] Available: http://www.iht.com/bin/printfriendly.php?id=8252160. (2 December 2007).

Robinson, S. (2006). Nigeria’s Deadly Days. (Special Report) Time Magazine, London (Sunday, 22 May), Vol. $167,(21)$.

Rowell, A., Marriott, J. \& Stockman, L. (2005). The Next Gulf: London, Washington and Oil Conflict in Nigeria. London: Constable and Robinson.

Saliu, H.A., Luqman, S. \& Abdullahi, A.A. (2007). Environmental Degradation, Rising Poverty and Conflict: Towards an Explanation of the Niger Delta Crisis. Journal of Sustainable Development in Africa 9 (4), $275-290$.

Sunday Trust Newspaper. (nd). How Asari Dokubo Plans To Tackle Hostage Taking. [Online Edition] Available: http://dailytrust.com. (15 August 2008).

Tamuno, T. (2000). The Niger Delta Question. Port Harcourt: Riverside Communications.

Tell Magazine. (2005). 18 April, 16-18.

The Comet Newspaper. (2001). 21 March, 12.

United Nations Development Programme (UNDP). (2006). Niger Delta Human Development Report. Lagos: UNDP.

Uyigue, E. \& Agho, M. (2007). Coping with Climate Change and Environmental Degradation in the Niger Delta of Southern Nigeria. Benin: Community Research and Development Centre (CREDC).

Uyigue, E. \& Ogbeibu, A.E. (nd). Climate Change and Poverty: Sustainable Approach in the Niger Delta Region of Nigeria. [Online]

http://www.2007amsterdamconference.org/Downloads/AC2007_UyigueOgbeibu.pdf. (18 January 2010).

Willinks Commission Report. (1957). Report of the Commission appointed to Enquire into the Fears of Minorities and the Means of Allaying them. London: Her Majesty's Stationery Office.

World Bank Report. (1995). Defining an Environmental Development Strategy for the Niger Delta (Vol. 1). Washington DC: The World Bank.

World Bank. (2003). Global Problems and Local Concern. Pathways to a Sustainable Future: Sustainable Development in a Dynamic World: Transforming Institutions' Growth and Quality of Life [World Development Report]. Washington DC: The World Bank.

\section{Notes}

Note 1. Oloibiri, a community near Port Harcourt city, is the very first community where oil was found (1956) and exploited in the delta. A typical 'natural museum' of the neglect that the Niger Delta has endured over the years, it is still a rural community lacking in almost all basic amenities - electricity, water, accessible roads, health and educational facilities and proper sanitation.

Note 2. Isaac Boro, alongside his associates, Sam Owonaro and Nottingham Dick, declared a short-lived independent Niger Delta Republic during the "12 Days Revolution" of 1967. Ken Saro-Wiwa's emergence and agitations (1993-1995) through his leadership of the Movement for the Survival of Ogoni People (MOSOP) took a little over two decades to come after the Boro-led revolt. Both rebellions were totally over oil-related environmental and economic grievances of the Niger Delta people. 


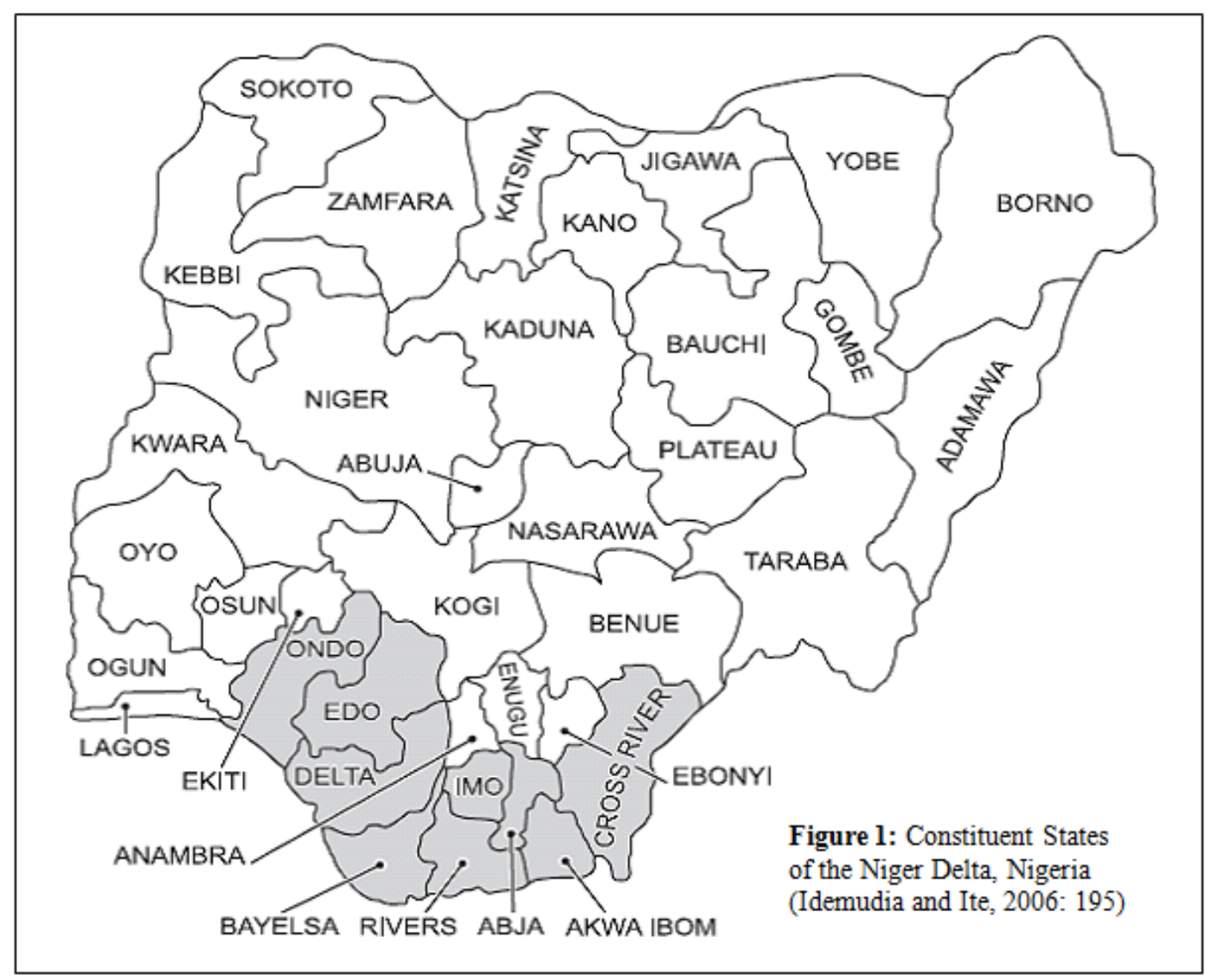

Figure 1. 